wound infection to the healthcare system as a whole are greater, because we did not take into account the physicians' and surgeons' charges to the provincial health insurance plan. Given that many hospitals in the United States are prospectively funded, surveying and preventing surgical-wound infections carries a potent financial incentive. ${ }^{13}$ In Canada, provincial government grants to hospitals are based increasingly upon productivity, and the increased length of stay attributable to surgical-wound infections serves to decrease the hospital's efficiency in providing surgical services to its community.

The Study of the Efficacy of Nosocomial Infection Control demonstrated that 35\% of surgicalwound infections could be prevented by an effective wound-infection surveillance and control program, and this has been corroborated by others. $9,11,14$ Detailed costing of each of the hospital resources utilized in caring for a patient with a surgical-wound infection is time-consuming and tedious. However, the AEP, modified for surgical-wound infections, provides a valid and readily applied tool for determining the attributable length of stay for surgical-wound infections. This information allows hospitals to assess the contribution wound infections make to excess length of stay and the impact nosocomial infection control programs have on preventing this common complication.

\section{REFERENCES}

1. Haley RW. Measuring the costs of nosocomial infections: methods for estimating economic burden on the hospital. Am J Med 1991;91:32S-38S

2. Wakefield DS, Helms CM, Massanari RM, Mori M, Pfaller M. Cost of nosocomial infection: relative contributions of laborato- ry, antibiotic, and per diem costs in serious Staphylococcus aureus infections. Am J Infect Control 1988;16:185-192.

3. Garner JS, Jarvis WR, Emori TG, Horan TC, Hughes JM. CDC definitions for nosocomial infections, 1988. Am J Infect Control 1988;16:128-140.

4. Wakefield DS, Pfaller M, Ludke RL, Wenzel RP. Methods for estimating days of hospitalization due to nosocomial infections. Med Care 1992;30:373-376.

5. Winickoff RN, Restuccia JD, Fincke BJ. Concurrent application of the appropriateness evaluation protocol to acute admissions in Department of Veterans' Affairs medical centers. Med Care 1991;29(suppl):AS64-AS76.

6. Wakefield DS, Pfaller MA, Hammons GT, Massanari RM. Use of the appropriateness evaluation protocol for estimating the incremental costs associated with nosocomial infections. Med Care 1987;25:481-488.

7. Gertman PM, Restuccia JD. The appropriateness evaluation protocol: a technique for assessing unnecessary days of hospital care. Med Care 1981;XIX:855-871.

8. Haley RW, Schaberg DR, Crossley KB, Von Allmen SD, McGowan JE Jr. Extra charges and prolongation of stay attributable to nosocomial infections: a prospective interhospital comparison. Am J Med 1981;70:51-58.

9. Haley RW. Managing Hospital Infection Control for Cost Effectiveness: A Strategy for Reducing Infectious Complications. Chicago, IL: American Hospital Publishing, Inc; 1986.

10. Green JW, Wenzel RP. Postoperative wound infection: a controlled study of the increased duration of hospital stay and direct cost of hospitalization. Ann Surg 1977;185:264-268.

11. Olson MM, Lee JT Jr. Continuous, 10-year wound infection surveillance: results, advantages, and unanswered questions. Arch Surg 1990;125:794-803.

12. Centers for Disease Control. Public health focus: surveillance, prevention, and control of nosocomial infections. MMWR 1992;41:783-787.

13. Haley RW, White JW, Culver DH, Hughes JM. The financial incentive for hospitals to prevent nosocomial infections under the prospective payment system. An empirical determination from a nationally representative sample. JAMA 1987;257:16111614.

14. Haley RW, Culver DH, White JW, Morgan WM, Emori TG, Munn VP, et al. The efficacy of infection surveillance and control programs in preventing nosocomial infections in US hospitals. Am J Epidemiol 1985;121:182-205.

\title{
Gerberding New Director of CDC's Hospital Infections Program
}

\section{Gina Pugliese, RN, MS} Martin S. Favero, PhD

The CDC has announced the appointment of Dr. Julie Gerberding as the new director of the Hospital Infections Program. Dr. Gerberding has been an Associate Professor of Medicine and of Epidemiology and
Biostatistics at the University of California, San Francisco, and Director of the Center for Epidemiology and Infection Prevention at San Francisco General Hospital. She is well known for her research in the risks of nosocomial and occupational transmission of bloodborne pathogens. Gerberding is the first person outside the CDC ranks and the first woman to direct the Hospital Infections Program. Past directors have included Richard Dixon, Robert Haley, James Hughes, William Martone, Martin Favero, and William Jarvis. Gerberding is scheduled to begin her new position in August 1998. 